Research Paper

\title{
Effect of Helixor A on Natural Killer Cell Activity in Endometriosis
}

In-Cheul Jeung, Youn-Jee Chung, Boah Chae, So-Yeon Kang, Jae-Yen Song, Hyun-Hee Jo, Young-Ok Lew, Jang-Heub Kim, Mee-Ran Kim ${ }^{凶}$

Department of Obstetrics and Gynecology, The Catholic University of Korea, Republic of Korea

$\triangle$ Corresponding author: Mee-Ran Kim, M.D., Ph.D., Professor, Department of Obstetrics and Gynecology, The Catholic University of Korea, 505 Banpo-Dong, Seocho-Gu, Seoul, 137-040, Korea. Tel : 82-2-2258-6170; Fax : 82-2-595-1549; E-mail: mrkim@catholic.ac.kr

(c) Ivyspring International Publisher. This is an open-access article distributed under the terms of the Creative Commons License (http://creativecommons.org/ licenses/by-nc-nd/3.0/). Reproduction is permitted for personal, noncommercial use, provided that the article is in whole, unmodified, and properly cited.

Received: 2014.07.09; Accepted: 2014.10.21; Published: 2015.01.01

\begin{abstract}
Background and Aim: NK cells are one of the major immune cells in endometriosis pathogenesis. While previous clinical studies have shown that helixor $A$ to be an effective treatment for endometriosis, little is known about its mechanism of action, or its relationship with immune cells. The aim of this study is to investigate the effects of helixor A on Natural killer cell (NK cell) cytotoxicity in endometriosis

Materials and Methods: We performed an experimental study. Samples of peritoneal fluid were obtained from January 2011 to December 2011 from 50 women with endometriosis and 50 women with other benign ovarian cysts (control). Peritoneal fluid of normal control group and endometriosis group was collected during laparoscopy. Baseline cytotoxicity levels of NK cells were measured with the peritoneal fluid of control group and endometriosis group. Next, cytotoxicity of NK cells was evaluated before and after treatment with helixor A. NK-cell activity was determined based upon the expression of CD107a, as an activation marker.

Results: NK cells cytotoxicity was $79.38 \pm 2.13 \%$ in control cells, $75.55 \pm 2.89 \%$ in the control peritoneal fluid, $69.59 \pm 4.96 \%$ in endometriosis stage $\mathrm{I} / \mathrm{ll}$ endometriosis, and $63.88 \pm 5.75 \%$ in stage III/IV endometriosis. A significant difference in cytotoxicity was observed between the control cells and stage III/IV endometriosis, consistent with a significant decrease in the cytotoxicity of NK cells in advanced stages of endometriosis; these levels increased significantly after treatment with helixor $A ; 78.30 \%$ vs. $86.40 \%(p=0.003)$ in stage $\mathrm{I} / / \mathrm{l}$ endometriosis, and $73.67 \%$ vs. $84.54 \%(p=0.024)$ in stage III/IV. The percentage of cells expressing CD 107a was increased significantly in each group after helixor $A$ treatment; $0.59 \%$ vs. $1.10 \%(p=0.002)$ in stage $\mathrm{I} / \mathrm{ll}$ endometriosis, and $0.79 \%$ vs. $1.40 \%(p=0.014)$ in stage III/IV.

Conclusions: Helixor A directly influenced NK-cell cytotoxicity through direct induction of CD 107a expression. Our results open new role of helixor $A$ as an imune modulation therapy, or in combination with hormonal agents, for the treatment of endometriosis.
\end{abstract}

Key words: Endometriosis, Natural Killer cells, Cytotoxicity, Helixor

\section{INTRODUCTION}

Endometriosis is a poorly understood disease characterized by the ectopic growth of endometrial cells in the pelvic cavity or other extrauterine sites. This widespread, estrogen-dependent disease is found in upwards $10 \%$ of all reproductive-age fe- males, including $35-50 \%$ of those suffering from chronic pelvic pain and infertility [1-3].

Recently studies examining the immunologic changes associated with endometriosis have demonstrated the importance of two major immune cells in 
disease pathogenesis: macrophages and NK cells. The number of macrophages has been shown to be increased in the peritoneal fluid of patients with endometriosis [4]; however, these cells failed to act as scavengers of endometrial tissues. Instead, these macrophages facilitated the proliferation of endometrial cells by secreting a number of cytokines, growth factors, and prostaglandins [5]. In contrast, the number of NK cells appears to be decreased in both the blood and peritoneal fluid of these patients [6], along with an overall decrease in NK-cell activity [6-8]. These results have been replicated in a number of other studies $[9,10]$, with the decrease in NK-cell activity being inversely proportional to severity of the disease [11]. Similar effects have not been seen for B cells, with conflicting results regarding the changes in B-cell populations $[12,13]$.

Mistletoe extracts have been shown to exert a wide range of immunologic effects, including increases in macrophage activity, proliferation of neutrophils, C-reactive protein levels, cytotoxic complement activation, and NK-cell cytotoxicity by inducing $\mathrm{CD}^{+}{ }^{+} \mathrm{CD} 4{ }^{+} \mathrm{T}$ cells to release IFN- $\gamma$ [14]. Based upon these findings, a variety of mistletoe formulations have been investigated for the treatment of breast and colorectal cancer, with preliminary results suggesting efficacy in both the treatment of cancers and the prevention of recurrence [15].

Helixor A is a whole-plant extract of the white mistletoe tree (Viscum album abietis). In this study we chose to evaluate the effects of helixor A on NK cells harvested from the peritoneal fluid of female patients with chronic recurrent endometriosis, and in those who have responded poorly to existing treatments. The mechanism by which helixor A affects NK cell cytotoxicity was also examined.

The aim of this study was to confirm a decrease in the cytotoxicity of NK cells in the peritoneal fluid of endometriosis patients. Furthermore, we sought to investigate the effects of helixor A on NK-cell cytotoxicity by comparing the expression of the activation marker CD107a before and after helixor A treatment. Together, these results provide insight into the mechanisms of disease pathogenesis, and suggest a role for helixor A in the treatment of acute and recurrent endometriosis.

\section{MATERIALS AND METHODS}

\section{Peritoneal fluid collection}

We collected peritoneal fluid from 100 females between the ages of 20 and 40, who underwent laparoscopic surgery for endometriosis or other benign diseases such as ovarian dermoid cysts or uterine leiomyoma between January and December 2011. All the 50 patients selected as cases had ednometriosis and all 50 patients selected as controls had ovarian dermoid cysts or uterine leiomyoma. This study was approved by the Institutional Review Board of the Catholic university of Korea according to the Bioethics and Safety Act and Declaration of Helsinki (IRB ID-DC12TAS10022). Patients reporting additional diseases of the uterus and adnexa, infectious diseases, previous endometriosis treatment, autoimmune diseases, or other malignancies were excluded from the study. These patients underwent surgery during early proliferative phase of the cycle without previous hormone therapy. All operations were performed laparoscopically. Under general anesthesia, a pneumoperitoneum was formed using a penetration tube, creating a cavity from which untreated peritoneal fluid could be collected. Out of the 50 cases patients, only 12 patients with endometriosis were selected for the study, and of the 50 patients selected as control, 3 with ovarian dermoid cysts and 3 with uterine leiomyoma were included in study. The harvested peritoneal fluid was then centrifuged at 1,300 rpm for 5 min, and the supernatant stored at $-70^{\circ} \mathrm{C}$. The clinical stages of endometriosis were determined using the revised American Society for Reproductive Medicine classification system. Patients were divided into two groups; group A comprised patients in stage I $(n=7)$, and group $B$ comprised patients in stage IV $(n=5)$.

\section{Cell Culture and Treatment}

NK-92 cells (CRL-2407TM, Korea Research Institute of Bioscience \& Biotechnology Bio-Resource Center) were cultured at a concentration of $5 \times 10^{5} / \mathrm{mL}$ in a-MEM media supplemented with $20 \%$ fetal bovine serum (FBS), $10 \mathrm{ng} / \mathrm{mL}$ IL-2, and antibiotics at $37^{\circ} \mathrm{C}$ in a $5 \% \mathrm{CO}_{2}$ incubator. $\mathrm{K} 562$ cells (ATCC, USA) were cultured as target cells in DMEM/F12 media supplemented with $10 \%$ FBS and antibiotics at $37^{\circ} \mathrm{C}$ in a $5 \% \mathrm{CO}_{2}$ incubator. $1 \times 10^{4}$ cells $(\mathrm{CON})$ were cultured in 96-well plates (Costar Products, Cambridge, MA, USA) and treated with $10 \%$ each of control peritoneal fluid $(\mathrm{CP})$, endometriosis stage I/II (EPI) peritoneal fluid, and endometriosis stage III/IV (EPIV) peritoneal fluid for $24 \mathrm{~h}$. After cell culture, wells were treated with 100, 200, 500, and $1000 \mathrm{ng} / \mathrm{mL}$ helixor A for $24 \mathrm{~h}$. NK-cell cytotoxicity was then assessed to determine the optimum concentration of helixor A. Helixor $A{ }^{\circledR}$ (Boryung Co. Seoul, Korea) is used as a mistletoe.

\section{NK-cell Cytotoxicity Assay}

K562 cells sensitive to NK-cell cytotoxicity were used as target cells. For NK-cell assays, $2.5 \times 10^{5}$ effector cells in medium alone or in medium supplemented with PF (10\% peritoneal fluid), were 
co-incubated with $1 \times 10^{4} \mathrm{~K} 562$ target cells in a final volume of $200 \mu \mathrm{L}$ in 96-well round-bottom plates for $24 \mathrm{~h}$ at $37^{\circ} \mathrm{C}$ in a $5 \% \mathrm{CO}_{2}$ humidified incubator. Cell density was assessed by incubating cells with 3-(4,5-dimethylthiazol-2-yl)-2,5-diphenyl-tetrazolium bromide (MTT, Colorimetric assay kit, Chemicon Inc., CA, USA) for $2 \mathrm{~h}$. The optical density of each well was determined at $450 \mathrm{~nm}$. Cytotoxic activity is expressed as the percentage of total cytotoxicity by the following formula: $\%$ Cytotoxicity $=\{1-$ O.D. of $[$ (target cells + effector cells)- effector cells] / O.D. of target cells $\} \times$ 100 .

\section{Flow Cytometric Analysis of NK-cell Apoptosis}

Cells $\left(1 \times 10^{4} ; \mathrm{CON}\right)$ were cultured in six-well plates and treated with $10 \%$ each of control peritoneal fluid (CP), endometriosis stage I/II (EPI) peritoneal fluid, and endometriosis stage III/IV (EPIV) peritoneal fluid for $24 \mathrm{~h}$, and then treated with $200 \mathrm{ng} / \mathrm{mL}$ of helixor A for $24 \mathrm{~h}$. The cells were washed with cold PBS and bovine serum, and resuspended in $1 \times$ binding buffer at a concentration of $1 \times 10^{6}$ cells $/ \mathrm{mL}$. Next, $100 \mu \mathrm{L}$ of the solution $\left(1 \times 10^{5}\right.$ cells) were transferred to a $5-\mathrm{mL}$ culture tube, to which $5-\mu \mathrm{L}$ FITC Annexin V and $5-\mu \mathrm{L}$ propidium iodide (PI) were added [16]. The cells were stirred gently, incubated at RT $\left(25^{\circ} \mathrm{C}\right)$ in the dark for $15 \mathrm{~min}$, and $400 \mu \mathrm{L}$ of $1 \times$ binding buffer were added to each tube. NK-cell apoptosis was analyzed by flow cytometry (FACScan, Becton-Dickinson, Mountain View, CA, USA) within $1 \mathrm{~h}$.

\section{Flow Cytometric Analysis of CD 107a Expression}

CD107a is directly involved in the exocytosis of cytotoxic granules, and is therefore the preferred marker for examination of NK cell activation. The

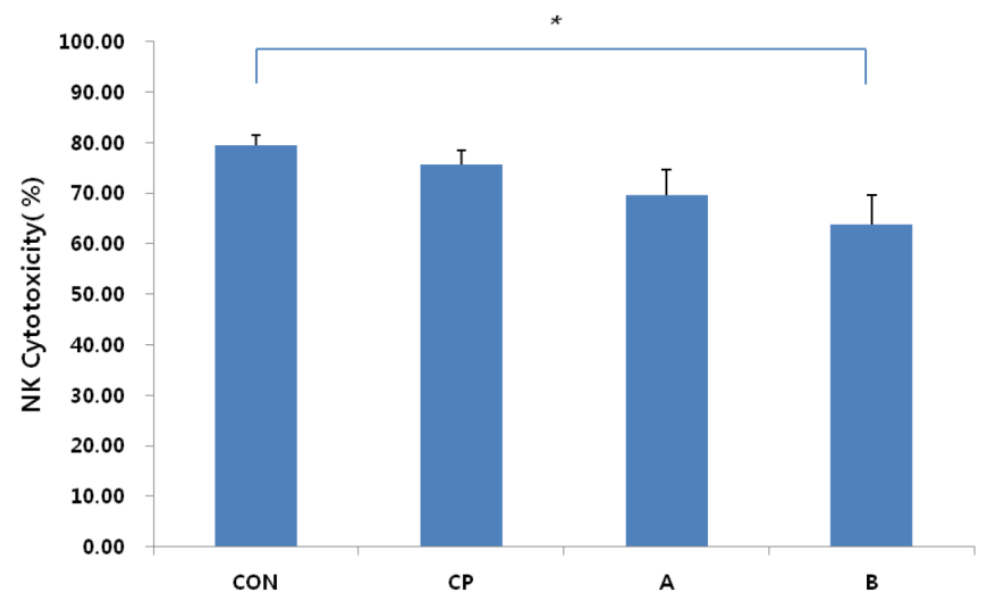

Fig. 1. Assessment of NK-cell cytotoxicity in endometriotic peritoneal fluid. The cytotoxicity of NK cells decreased in proportion to the stage of endometriosis. Cytotoxicity of NK cells was decreased significantly in late-stage endometriosis patients (group B) relative to the cell control (CON). CON: cell control, CP: control peritoneal fluid, A: endometriosis stage I/II peritoneal fluid, B: endometriosis stage III/IV peritoneal fluid. $* P<0.05$. above solution (100 $\mu \mathrm{L} ; 1 \times 10^{5}$ cells) was transferred to a $5-\mathrm{mL}$ culture tube and treated with $20-\mu \mathrm{L}$ CD107a-PeCy5 antibody (BD Biosciences, San Jose, CA)[17]. The cells were stirred gently, incubated at RT $\left(25^{\circ} \mathrm{C}\right)$ in the dark for $45 \mathrm{~min}$, and $400 \mu \mathrm{L}$ of $1 \times$ binding buffer was added to each tube. CD107a expression was analyzed by flow cytometry within $1 \mathrm{~h}$.

\section{Statistical Analysis}

Data were analyzed by one-way ANOVA using the SPSS version 18.0 software (SPSS Korea Data Solution Inc.). After comparing the standard error of the mean between groups, a value of $p<0.05$ was taken to indicate statistical significance.

\section{RESULTS}

The cytotoxicity of NK cells was measured using the immortalized myelogenous leukemia cell line K562 as a target. NK cells cytotoxicity was 79.38 \pm $2.13 \%$ in control cells, $75.55 \pm 2.89 \%$ in the control peritoneal fluid, $69.59 \pm 4.96 \%$ in endometriosis group A, and $63.88 \pm 5.75 \%$ in group B (Fig. 1). A significant difference in cytotoxicity was observed between the control cells and endometriosis group B, consistent with a significant decrease in the cytotoxicity of NK cells in advanced stages of endometriosis $(p=0.012)$.

Next, we examined the effects of helixor A on NK-cell cytotoxicity. To determine the optimum dose, NK cells were treated with 100, 200, 500 and 1000 $\mathrm{ng} / \mathrm{mL}$ of helixor A concentrations, and assessed for cytotoxicity. No significant differences in NK-cell cytotoxicity were observed among the groups, although the highest level was in the $200 \mathrm{ng} / \mathrm{mL}$ helixor A treatment group $(p=0.232)$; this concentration was therefore used in all subsequent experiments.

No significant difference in NK cell cytotoxicity was observed in control cells following helixor A treatment $(85.04 \pm 2.22 \%$ vs. $87.60 \pm 2.82 \%$ for control and treatment, respectively; $p=0.373$ ). However, an increase was seen in the control peritoneal fluid group, with cytotoxicity increasing from $81.64 \pm 3.41 \%$ to $87.75 \pm 2.27 \%$ ( $p=0.012)$ following treatment. More pronounced effects were seen in the endometriosis groups with $8 \%(78.30 \pm 4.00 \%$ vs. $86.40 \pm 4.64 \% ; p=0.003)$ and $9 \%(73.67 \pm 5.96 \%$ vs. $84.54 \pm 3.01 \% ; p=$ $0.024)$ increases in cytotoxicity in groups $A$ and $B$, respectively. Together, these data are indicative of a proportional increase in helixor-A-mediated NK-cell cytotoxicity according to disease stage (Fig.2).

Following treatment with helixor A, NK cells were also examined in terms of the expression of apoptotic markers. No significant 
difference in NK cell apoptosis was seen in the cell control group before and after treatment $(3.68 \pm 1.74 \%$ vs. $2.57 \pm 1.12 \%$ ). Similar results were observed in the peritoneal control group $(1.94 \pm 0.50 \%$ vs. $1.93 \pm 0.22 \%)$, as well as endometriosis groups A $(1.74 \pm 0.26 \%$ vs. $1.77 \pm 0.77 \%)$, and B $(1.49 \pm 0.22 \%$ vs. $1.27 \pm 0.71 \%)$ for controls and treatments, respectively $(p=0.373$; Fig. $3)$.

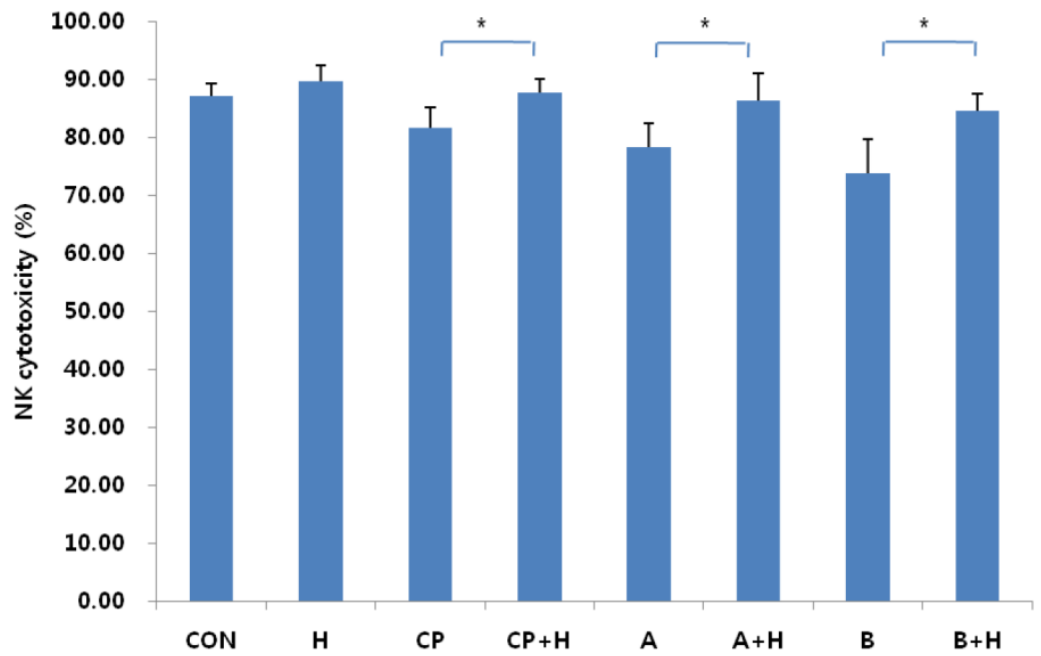

Fig. 2. Changes in NK-cell cytotoxicity after treatment with helixor A. Changes in NK-cell cytotoxicity were analyzed by flow cytometry before and after addition of $200 \mathrm{ng} / \mathrm{mL}$ helixor A. The cytotoxicity of NK cells was increased significantly in peritoneal controls and endometriosis. CON: cell control, CP: control peritoneal fluid, A: endometriosis stage I/II peritoneal fluid, B: endometriosis stage III/IV peritoneal fluid, $+\mathrm{H}: 200 \mathrm{ng} / \mathrm{mL}$ helixor $\mathrm{A}$ treatment. $* P<0.05$.

Fig. 3. Apoptosis of NK cells following treatment with helixor $\mathbf{A}$. The rate of NK cell apoptosis was analyzed by FACS before and after treatment with helixor A. (A) No differences were seen in either early or late apoptosis, as measured by FITC Annexin $\mathrm{V}$ and propidium iodide staining (PI), respectively. (B) Comparison of the mean percentage of apoptotic cells before and after treatment. No significant differences in the mean percentage of apoptotic cells were seen before and after treatment with helixor $A$ (CON: cell control, CP: control peritoneal fluid, $\mathrm{A}$ : endometriosis stage $\mathrm{I} / \mathrm{II}$ peritoneal fluid, $\mathrm{B}$ : endometriosis stage III/IV peritoneal fluid, $+\mathrm{H}$ : $200 \mathrm{ng} / \mathrm{mL}$ helixor A treatment).
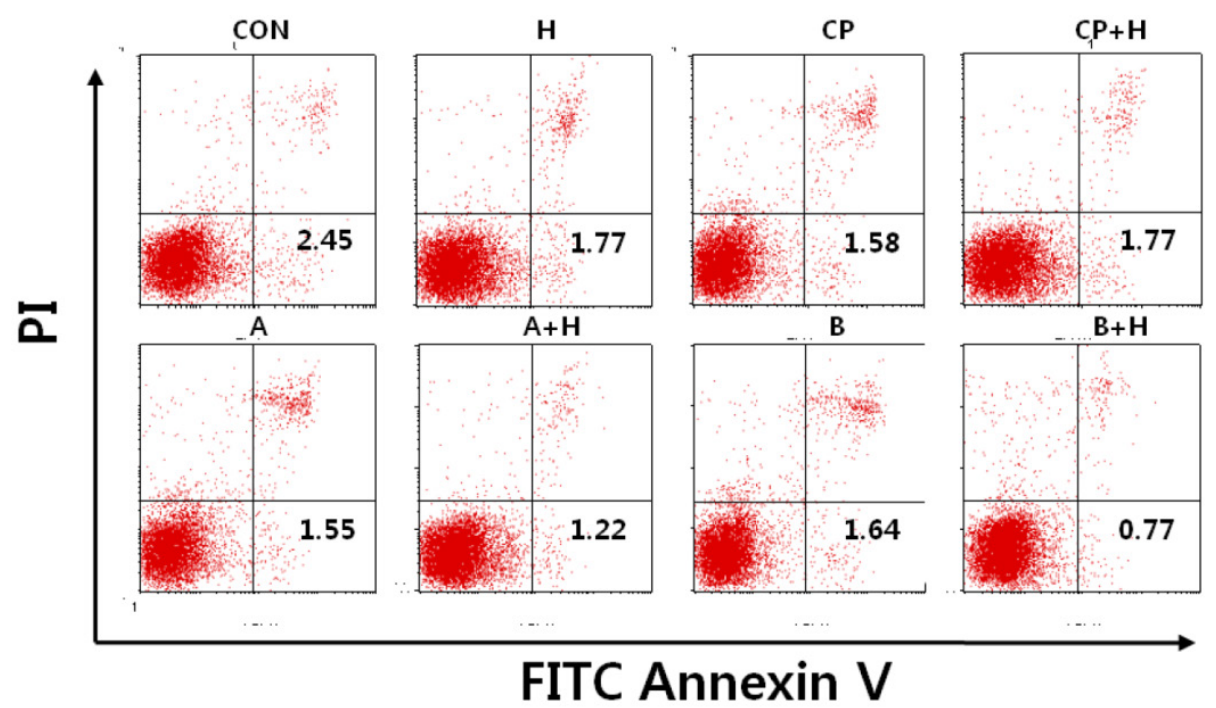

\section{FITC Annexin V}

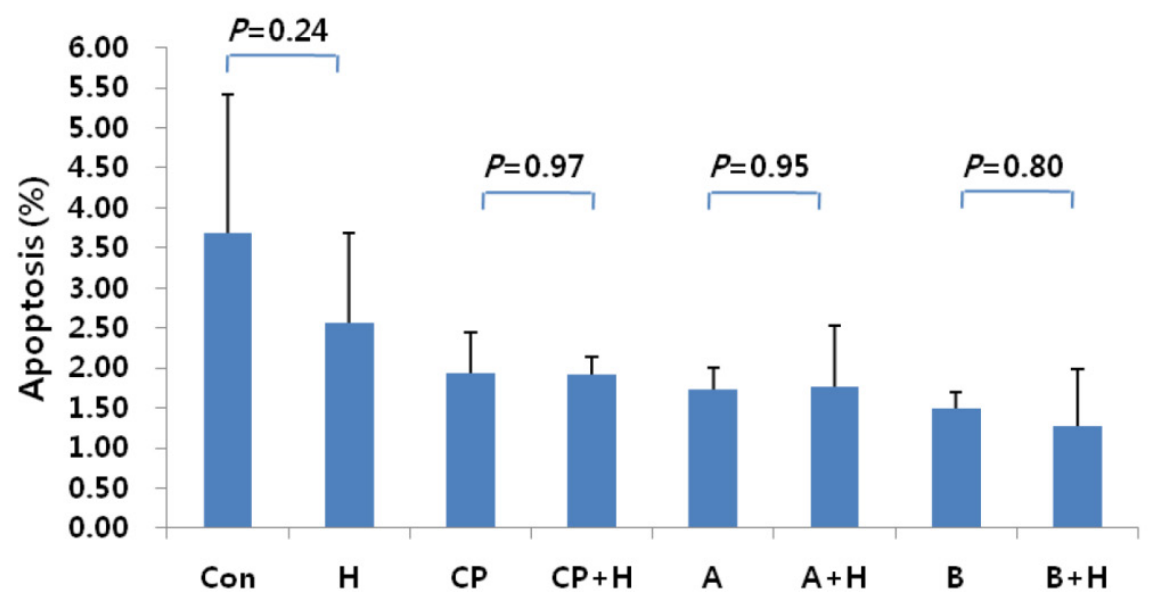




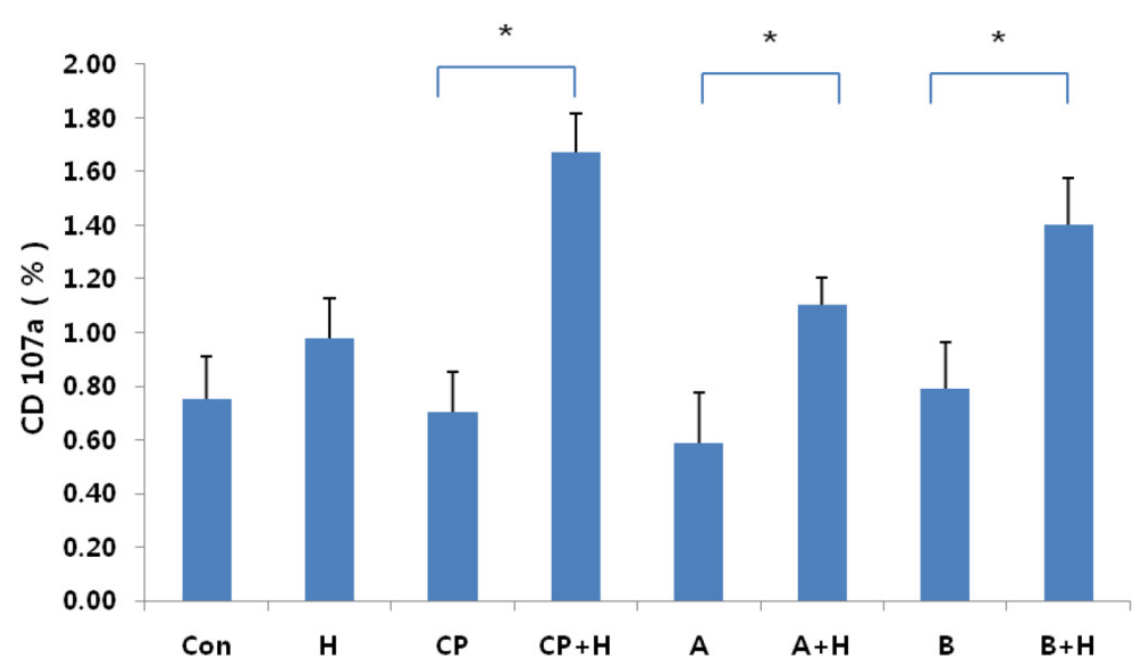

Fig. 4. Expression of CD 107a following treatment with helixor $A$. Expression of $C D 107$ a by NK cells was measured before and after treatment with helixor A. Significant increases in CD 107a expression were observed following treatment with helixor A; this is consistent with cell activation. CON: cell control, CP: control peritoneal fluid, A: endometriosis stage I/II peritoneal fluid, B: endometriosis stage III/IV peritoneal fluid, $+\mathrm{H}: 200 \mathrm{ng} / \mathrm{mL}$ helixor $\mathrm{A}$ treatment. $* P<0.05$.

To assess NK-cell activation, we examined the level of CD107a expression before and after treatment with helixor A. CD107a is directly involved in the exocytosis of cytotoxic granules, and is therefore the preferred marker for examination of NK cell activation. No significant difference in CD107a expression was seen in the cell control group before and after treatment $(0.75 \pm 0.20 \%$ vs. $0.98 \pm 0.10 \%$, respectively; $p$ $=0.140)$. However, significant increases were seen in all other groups following treatment (Fig. 4); the control peritoneal fluid group exhibited a $\sim 2$.4-fold increase in CD107a expression following treatment (0.70 $\pm 0.20 \%$ vs. $1.67 \pm 0.10 \%(p=0.012)$, while the endometriosis groups exhibited 1.8 -fold $(0.59 \pm 0.20 \%$ vs. $1.10 \pm$ $0.10 \% ; p=0.02)$ and 1.9 -fold $(0.79 \pm 0.20 \%$ vs $1.40 \pm$ $0.20 \% ; p=0.014)$ increases in CD107a expression in NK cells following treatment, for groups A and B, respectively. Taken together, these results suggest that helixor A increases NK-cell cytotoxicity through direct induction of CD107a expression.

\section{DISCUSSION}

NK cell dysfunction is seen more frequently than either B- or T-cell malignancies in immunologic studies of endometriosis [18]. Increased levels of IL-12p40 in the peritoneal fluid of endometriosis patients have been shown to inhibit the activity of IL-12 in NK cells, leading to a significant reduction in NK-cell function [19]. Recent studies have reported that an increase in KIR2DL1, a modified type of killer cell inhibitory receptor (KIRs), directly suppressed NK-cell function and reduced NK-cell activity [20]. This study revealed a decrease in NK-cell activity in patients with endometriosis, with the degree of NK-cell dysfunction being directly associated with disease stage. These data are consistent with a role for NK cells as a scavenger of endometrial cells outside of the uterus, and as a regulator of disease progression.

Standard treatments for endometriosis, including hormone suppression therapy and surgical removal of endometrial lesions, do not improve NK-cell activity [21]. Moreover, disease recurrence in increased significantly in patients with low NK-cell activity $[22,23]$. Taken together, these data suggest a central role for NK cells in the development and recurrence of endometriosis. Therapies capable of either normalizing or increasing NK-cell activity are therefore necessary to reduce the rate of recurrence in endometriosis patients. One such study has been performed, showing that an improvement in NK-cell activity led to a reduction in endometriosis lesions [24]. Based upon these results, helixor A is expected to be an effective therapeutic agent in the treatment of endometriosis due to its ability to regulate NK-cell function.

Under normal conditions, NK-cell cytotoxicity is mediated through the release of cytoplasmic granules containing perforins and granzymes, which directly target malignant cells [25]. Although there are a variety of methods for evaluating the cytotoxicity of NK cells, CD107a expression remains the best-validated marker of NK-cell activation [26]. This study focused on the exocytosis of perforins and granzymes from NK cells as a mechanism for clearance of ectopic endometrial cells. Our results showed a significant increase in CD107a expression following treatment with helixor A, suggesting that this might be useful for the treatment of endometriosis.

While previous clinical studies have shown helixor A to be an effective treatment for relieving pain and other symptoms associated with endometriosis, little is known about its mechanism of action, or its 
relationship with immune cells[27]. This study suggests one of the possible mechanisms of action that helixor A plays a role in NK cell activity, mediated by direct induction of CD107a expression. These findings may help to pave the way for the expanded use of helixor A in the treatment of endometriosis. Moreover, it is thought that using helixor A in combination with standard therapeutic regimens may be effective in patients with recurrent endometriosis after primary or hormone suppression treatment.

Future studies evaluating the use of helixor A is a mouse model of endometriosis are necessary before any clinical trials will be possible. A study of the effects of helixor A on endometrial lesions and the normalization of cytotoxic function in NK cells in vivo is needed to fully understand the mechanism of helixor A activity. Analysis of the peritoneal fluid of endometriosis patients to confirm the association between the recovery of NK-cell function, reduction of lesions, and prevention of recurrence, is also warranted. Additional studies of the effects of helixor A on other immune cells, and the resulting effect of cytokines on NK-cell activity, must also be performed. Together, these studies will determine whether helixor A can be used as a monotherapy, or in combination with hormonal agents, for the treatment of endometriosis.

\section{ACKNOWLEDGEMENTS}

This research was supported by a grant from the National Research Foundation of Korea funded by the Korean Government (2009-0073040), and by the Basic Science Research Program of the National Research Foundation of Korea (NRF), funded by the Ministry of Education, Science and Technology (2010-0002724).

\section{Competing Interests}

The authors have declared that no competing interest exists.

\section{References}

1. Cramer DW, Missmer SA. The epidemiology of endometriosis. Annals of the New York Academy of Sciences. 2002; 955: 11-22; discussion 34-6, 396-406.

2. Eskenazi B, Warner ML. Epidemiology of endometriosis. Obstetrics and gynecology clinics of North America. 1997; 24: 235-58.

3. Kim D, Lee J, Bae D. The Prevalence of Endometriosis in Diagnostic Pelviscopy and Operative Pelvisopy. Kor J Obstet \& Gynecol 1996; 39: 2089-95.

4. Haney AF, Muscato JJ, Weinberg JB. Peritoneal fluid cell populations in infertility patients. Fertility and sterility. 1981; 35: 696-8.

5. Lebovic DI, Mueller MD, Taylor RN. Immunobiology of endometriosis. Fertility and sterility. 2001; 75: 1-10.

6. Kikuchi Y, Ishikawa N, Hirata J, Imaizumi E, Sasa H, Nagata I. Changes of peripheral blood lymphocyte subsets before and after operation of patients with endometriosis. Acta obstetricia et gynecologica Scandinavica. 1993; 72: 157-61.

7. Oosterlynck DJ, Cornillie FJ, Waer M, Vandeputte M, Koninckx PR. Women with endometriosis show a defect in natural killer activity resulting in a decreased cytotoxicity to autologous endometrium. Fertility and sterility. 1991; 56: 45-51.

8. Garzetti GG, Ciavattini A, Provinciali M, Fabris N, Cignitti M, Romanini C. Natural killer cell activity in endometriosis: correlation between serum estradiol levels and cytotoxicity. Obstetrics and gynecology. 1993; 81: 665-8.
9. Oosterlynck DJ, Meuleman C, Waer M, Vandeputte M, Koninckx PR. The natural killer activity of peritoneal fluid lymphocytes is decreased in women with endometriosis. Fertility and sterility. 1992; 58: 290-5.

10. Tanaka E, Sendo F, Kawagoe S, Hiroi M. Decreased natural killer cell activity in women with endometriosis. Gynecologic and obstetric investigation. 1992; 34: $27-30$.

11. Oosterlynck DJ, Meuleman C, Waer M, Koninckx PR, Vandeputte M. Immunosuppressive activity of peritoneal fluid in women with endometriosis. Obstetrics and gynecology. 1993; 82: 206-12.

12. Gagne D, Rivard M, Page M, Shazand K, Hugo P, Gosselin D. Blood leukocyte subsets are modulated in patients with endometriosis. Fertility and sterility. 2003; 80: 43-53

13. Chishima F, Hayakawa S, Hirata Y, Nagai N, Kanaeda T, Tsubata K, et al. Peritoneal and peripheral B-1-cell populations in patients with endometriosis. The journal of obstetrics and gynaecology research. 2000; 26: 141-9.

14. Kuttan G, Kuttan R. Immunological mechanism of action of the tumor reducing peptide from mistletoe extract (NSC 635089) cellular proliferation. Cancer letters. 1992; 66: 123-30.

15. Elsasser-Beile U, Voss M, Schuhle R, Wetterauer U. Biological effects of natural and recombinant mistletoe lectin and an aqueous mistletoe extract on human monocytes and lymphocytes in vitro. Journal of clinical laboratory analysis. 2000; $14: 255-9$.

16. Kasatori N, Ishikawa F, Ueyama M, Urayama T. A differential assay of NK-cell-mediated cytotoxicity in K562 cells revealing three sequential membrane impairment steps using three-color flow-cytometry. Journal of immunological methods. 2005; 307: 41-53. doi:10.1016/j.jim.2005.09.005.

17. Alter G, Malenfant JM, Altfeld M. CD107a as a functional marker for the identification of natural killer cell activity. Journal of immunological methods. 2004; 294: 15-22. doi:10.1016/j.jim.2004.08.008.

18. Milewski L, Dziunycz P, Barcz E, Radomski D, Roszkowski PI, Korczak-Kowalska G, et al. Increased levels of human neutrophil peptides 1, 2, and 3 in peritoneal fluid of patients with endometriosis: association with neutrophils, T cells and IL-8. Journal of reproductive immunology. 2011; 91: 64-70. doi:10.1016/j.jri.2011.05.008.

19. Mazzeo D, Vigano P, Di Blasio AM, Sinigaglia F, Vignali M, Panina-Bordignon P. Interleukin-12 and its free $\mathrm{p} 40$ subunit regulate immune recognition of endometrial cells: potential role in endometriosis. The Journal of clinical endocrinology and metabolism. 1998; 83: 911-6. doi:10.1210/jcem.83.3.4612.

20. Maeda N, Izumiya C, Oguri H, Kusume T, Yamamoto Y, Fukaya T. Aberrant expression of intercellular adhesion molecule-1 and killer inhibitory receptors induces immune tolerance in women with pelvic endometriosis. Fertility and sterility. 2002; 77: 679-83.

21. Oosterlynck DJ, Meuleman C, Waer M, Koninckx PR. CO2-laser excision of endometriosis does not improve the decreased natural killer activity. Acta obstetricia et gynecologica Scandinavica. 1994; 73: 333-7.

22. Garzetti GG, Ciavattini A, Provinciali M, Muzzioli M, Di Stefano G, Fabris N. Natural cytotoxicity and GnRH agonist administration in advanced endometriosis: positive modulation on natural killer activity. Obstetrics and gynecology. 1996; 88: 234-40

23. Umesaki N, Tanaka T, Miyama M, Mizuno K, Kawamura N, Ogita S. Increased natural killer cell activities in patients treated with gonadotropin releasing hormone agonist. Gynecologic and obstetric investigation. 1999; 48: 66-8. doi:10137.

24. Itoh H, Sashihara T, Hosono A, Kaminogawa S, Uchida M. Lactobacillus gasseri OLL2809 inhibits development of ectopic endometrial cell in peritoneal cavity via activation of NK cells in a murine endometriosis model. Cytotechnology. 2011; 63: 205-10. doi:10.1007/s10616-011-9343-z.

25. Smyth MJ, Hayakawa Y, Takeda K, Yagita H. New aspects of natural-killer-cell surveillance and therapy of cancer. Nature reviews Cancer. 2002; 2: 850-61. doi:10.1038/nrc928.

26. Tomescu C, Chehimi J, Maino VC, Montaner LJ. Retention of viability, cytotoxicity, and response to IL-2, IL-15, or IFN-alpha by human NK cells after CD107a degranulation. Journal of leukocyte biology. 2009; 85: 871-6. doi:10.1189/jlb.1008635.

27. Rim SY, Oh ST. The Effect of intraperitoneal instillation of Mistletoe extract during the diagnostic laparoscopy for pain of endometriosis. Korean J Obstet Gynecol. 2005; 48: 1004-8. 